\title{
Research on Water Pollution.
}

A

COMMITTEE has been set up, under the chairmanship of Sir Horace Monro, to deal with the legislative and administrative aspects of questions relating to river pollution. This committee considers that present legislative enactments are sufficient, and recommends the setting up of River Boards in the various watersheds of England. Such Boards, having a call upon the rates, would be in a financial position to apply the laws against pollution, a costly activity which rarely appeals to private individuals. They would be in a position to employ a technical adviser conversant with local conditions and with known means of dealing with noxious effluents. It remains to be seen whether county councils will act on this advice and set up a series of Boards throughout Great Britain, similar to that in the West Riding of Yorkshire.

Although much has been done recently in surveying rivers and locating sources of pollution, many of which could be stopped or at least ameliorated without putting undue burdens upon the rates or upon individual industries, there are also numerous questions which, in the interests of the public, have still to be worked out.

With this aim in view, the Water Pollution Research Board was formed in June 1927, with Sir Robert Robertson as chairman and Dr. H. Calvert, chemical Inspector of the Ministry of Health, as part-time director of research. They have undertaken the three-fold task: "To collect and collate all pertinent scientific and technical information, so that it may be readily available for practical application by those who are concerned with water supply and the disposal of polluting liquids ; to encourage and coordinate relevant scientific research in this country; and to undertake such investigations as are necessary in the public interest and not otherwise provided for."

A good start has been made. The monthly summaries of current literature, of which some seventy copies are distributed, are excellent and will be of material assistance not only to those concerned with water purification and wastes disposal but also to many workers in hydrobiology. In the report of the Board for the year 1927-1928 (H.M. Stationery Office, $6 d$.) an account is given of investigations now proceeding and of plans for the near future.

The disposal of effluent waters from beet sugar factories presents a problem which had early in the year been 'farmed out' by the Ministry of Agriculture and Fisheries for investigation at Rotham sted. Each factory uses some $3 \frac{1}{2}$ million gallons of water daily, of which nearly half a million gallons are discharged containing putrifiable matter comparable to $0 \cdot 2$ per cent sucrose. It is found that by sprinkling this water over a biological filter at a rate of 100 gallons per square yard daily, its putresibility is reduced by some 80 per cent. Trial filters were erected at the Colwick factory and filled with different media. Two were seeded with active growth from a sewage filter, but this inoculation had no observable effect on the maturing of the filters. The growth on coarse gravel consisted of thickly matted fungi, while on the finer media the growth was soft and composed.chiefly of bacteria; the flora and fauna on the filters differed and were distinct from the flora and fauna of ordinary sewage filters. The purification attained cannot be regarded as sufficient to meet the most exacting requirements, but still better results are expected from the past winter's campaign.

It is anticipated that the effluents may be made fit

$$
\text { No. 3102, VoL. 123] }
$$

for re-use in the factory, a practice which is already in operation in some cases, so that the daily discharge into the rivers will be reduced to a reasonable amount for treatment on biological filters.

A biologist has been appointed to work under the direction of Prof. Topley at the London School of Hygiene and Tropical Medicine, on the processes involved in the treatment of sewage by 'activated sludge.' The solids of sewage after aeration become capable of flocculating colloidal matter and removing dissolved organic substances from further volumes of sewage. In doing so the aerated solids, or "activated sludge, lose their activity, which can, however, be restored by further aeration. There is, however, little exact knowledge of the process and it is yet uncertain whether it is physico-chemical or the direct effect of micro-organisms. The de-watering and the production of gas from sludge or sewage also engage the attention of the board.

It is considered that a general biological and chemical survey of a typically polluted river would furnish information of general value as well as local information. Such a survey should yield much new knowledge of river conditions generally, of the interaction between the river and the various effluents - their direct or indirect effect upon the flora and fauna. The Tees is suggested as a suitable watershed, the river having been under examination for several years and useful data already collected. Undoubted damage has been done by pollution, but the nature of the damage and the various causes still offer a wide field for investigation.

In all these matters the main part is played by micro-organisms-the unpaid scavengers of every borough. How they are best harnessed to destroy unwanted organic matter most efficiently, and even to break down naphthalene in coke-oven effluents, provide outstanding problems.

Compared with some continental countries, England is behindhand in providing facilities for the general study of freshwater biology and hydrology. These subjects are no longer of academic interest only, for they enter into many economic problems within the Empire. Mosquito control and tropical lake fishery investigations, for example, are in present need of information and recruits, which should normally come from an English freshwater biological laboratory, similar to the marine laboratory at Plymouth, where more than twenty visitors are at times working on varied researches during the university vacations. That the Rivers Pollution Research Board will act as a valuable clearing-house for information is assured. We hope it may encourage the institution of a laboratory for post-graduate workers near pools, lakes, and a river-a facility for which there is a present demand. The study of aquatic life and of the breakdown of organic matter by micro-organisms is not merely of domestic interest.

The Board has also arranged for the investigation of the softening of water by the process in which it is allowed to trickle through beds of natural or artificial zeolite containing sodium in chemical combinations. The sodium is displaced by the calcium and magnesium of the hard water, and the beds are finally rejuvenated by displacing the calcium and magnesium held by them with a solution of common salt. The mode of action of the base-exchanges is very imperfectly understood from the physicochemical point of view. The process is in extensive use, but is little used by water-supply authorities as yet. 